\title{
Vägar till ett akademiskt skriftspråk
}

\section{Av Sofia Ask}

I den här artikeln presenteras några enkätundersökningar om studenter och studenters skrivande. Därefter redovisas resultatet av en enkätundersökning om studenters uppfattningar om akademiskt skrivande som genomfördes vid Växjö universitet under vårterminen 2005. Enkäten föregick djupintervjuer med tio lärarstudenter som ingår i mitt avhandlingsarbete.

\section{Nya studenter i stadieövergången}

I en enkätundersökning där 100 nya lärarstudenter som just tagit steget över från gymnasieskolan till universitetet deltar, framkommer att de i stort inte upplever att den gymnasieutbildning de har erfarenhet av förberett dem för universitetsstudier i särskilt hög grad (Ask 2005a: 119). Studenterna anser i olika utsträckning att övergången varit svår, och att de ser få kopplingar mellan gymnasieskola och universitet. Särskilt svårt upplever män från yrkesförberedande program det, medan både män och kvinnor med bakgrund på de studieförberedande programmen upplever övergången som lättare. Denna sistnämnda grupp har också i stor utsträckning personer med akademisk erfarenhet i sin omgivning som de kan hämta stöd och hjälp hos (Ask 2005b: 106ff).

Vid Göteborgs universitet drivs projektet "Övergången från gymnasieskolan till universitetet" (ÖGUS 2006). I detta projekt undersöks förhållandet mellan gymnasielärares, studenters och universitetslärares uppfattningar om svenskämnet i högre utbildning och på gymnasieskolan. Inom projektet diskuteras frågor som hur universitetslärare skall förhålla sig till gymnasieskolan i frågor om ämnesinnehåll, ämneskonception och nya arbetssätt. I ÖGUS-projektet analyseras hur stadieövergången uppfattas av lärare och studenter i syftet att undersöka svenskämnets konstruktion, vad som påverkar undervisningen och vilken ämneskonception deltagarna har. Även universitetslärares uppfattningar om studenternas förkunskaper och färdigheter är föremål för ÖGUS-projektets undersökning. Dessutom undersöks studenters förväntningar när de börjar läsa svenska och hur olika moment inom ämnet uppfattas, både på gymnasie- och universitetsnivå.

Rapporten Väl förberedd? Arbetsledare och lärare på högskolor bedömer gymnasieutbildades färdigheter. En utvärdering av gymnasieskolan utifrån mottagarnas perspektiv (Skolverket 2005) visar att avnämarna, det vill säga representanter för arbetsliv och högre utbildning, har olika uppfattningar om kunskaperna hos de individer de möter. Arbetslivsrepresentanterna ger elever som kommer direkt från gymnasieskolan goda färdighetsomdömen. Det handlar främst om gott ordningssinne, intresse och framåtanda. Även samarbetsförmåga skattas högt. Dock kritiseras elevernas bristande förkunskaper i matematik. Sammantaget menar avnämarna att eleverna idag är bättre rustade för arbetslivet än de var för 5-10 år sedan (2005:9). I högre studier är uppfattningen den motsatta. Drygt 1600 universitets- och högskolelärare tillfråga- 
des i samma studie om de nya studenternas förhållningssätt, förkunskaper och färdigheter. Det visar sig då att lärarna anser att studenterna har otillräckliga förkunskaper och är ovana vid att analysera och problematisera. Studenternas läs- och skrivförmåga ansågs också vara bristfällig. De medverkande lärarna inom området för humaniora framhåller att studenterna idag är sämre rustade för högre studier än de var för 5-10 år sedan (2005: 10).

\section{Studenter på högskolan}

I en undersökning kallad Med studenternas egna ord (Brandell \& Höög 1998) ställs frågor om vad det innebär att vara student, vad man lärt sig och vad som skulle kunnat vara annorlunda under utbildningstiden. Drygt 2000 studenter ingick i undersökningen, som gjordes på uppdrag av Högskoleverket. Resultaten visar bland annat att många studenter är kritiska mot undervisningen och lärarnas pedagogik. Äldre studenter med familj och barn är av den åsikten att dålig ekonomi och småbarn är två faktorer som gör studietiden krånglig (1998:9). En inställd föreläsning eller ett sjukt barn kan, enligt rapporten, skapa stora problem för den här studentgruppen.

Tre större enkätundersökningar av 200 lärarstudenters uppfattningar om den nya lärarutbildningen ingår i ett longitudinellt utvärderingsprojekt som drivs vid Uppsala universitet (Staaf 2002, 2004, 2006). Den första undersökningen gjordes 2002, då studenterna gick sin första termin, den andra gjordes 2004 då studenterna befann sig i mitten av sin utbildning. År 2006 var studenterna framme vid sin sjunde termin och undersökningen följdes upp och utvecklades. Ett resultat som redovisas där är hur synen på utbildningen förändras över tid. Blivande gymnasielärare och lärare för grundskolans senare år tenderar att vara mer kritiska mot utbildningen och har inte blivit mindre kritiska under utbildningens gång, snarare tvärt om. Två tredjedelar av studenterna har ändrat åsikt om lärarutbildningen under utbildningens gång. De har blivit mer negativt inställda än de var i början (2006:21).

\section{Studenter och språkliga praktiker i högre utbildning}

I projektet Studenters möte med universitetets språkmiljö undersöks "språkbruk, språkbakgrund, språkförändring och språkattityder till universitets- och högskolestudier" (Melander Marttala 2006). Enkätundersökningen, som omfattar 445 studenter vid Uppsala universitet och Södertörns högskola, inkluderar studenter både i början och slutet av utbildningstiden. Delar av undersökningsgruppen tillhör lärarutbildningen, men också delar av ekonomiutbildningen ryms inom ramen för undersökningen. Resultaten av enkätundersökningen visar bland annat att hälften av studenterna anser att lärare på universitetet eller högskolan ofta har ett svårt språk och att studenterna till mycket stor del (87 \%) anser att det finns en annorlunda kultur och ett annat språk inom högre utbildning. Det anses vara viktigt att tillägna sig ett fackspråk och studenterna säger också att de har ändrat sitt språk sedan de började studera på universitet och högskola. 


\section{Studenter i dubbel genomlysning}

I det här avsnittet redogör jag dels för en större allmän enkätundersökning av studenter vid Växjö universitet, dels för min egen enkät som fokuserar studenternas akademiska skrivande.

\section{Den typiska Växjöstudenten}

I en rapport kallad Växjöstudenterna och deras universitet (Eriksson m. fl. 2002) presenteras resultat från en större undersökning där sammanlagt 1500 studenter från Växjö universitet ingick. Resultaten bekräftar i viss mån de resultat jag själv kommer fram till i den mindre enkätundersökning som ingår i mitt avhandlingsarbete. Särskilt data om studenternas bakgrund finner jag stöd för i den större undersökningens resultat. I rapporten om Växjöstudenterna anges att majoriteten av de studerande på universitetet som helhet är kvinnor (60\%) (Eriksson m. fl. 2002:5). Så är också fallet i min undersökning. En stor majoritet av studenterna som svarade på frågorna i min enkät var kvinnor (85,9\%), vilket hänger samman med att kvinnodominansen på landets lärarutbildningar och i läraryrket är stor. Det finns helt enkelt fler kvinnor än män på lärarutbildningen. Statistik visar att "kvinnodominansen bland yngre lärar- och pedagogutbildade är större jämfört med äldre lärarutbildade. Endast 22 procent av de yngre är män” (SCB 2005).

Enligt Växjöundersökningen är en knapp majoritet (51\%) av studenterna ensamstående. I min undersökning var motsvarande siffra 23,6\%. I den större undersökningen uppger $20 \%$ att de har barn, medan siffran i min mindre undersökning av lärarstudenterna var $40 \%$. Att de är så pass många kan ha sin förklaring $i$ att lärarstudenterna ofta är något äldre än övriga studentgrupper och därför hunnit bilda familj och skaffa barn. Av studenterna i Växjöundersökningen uppger $80 \%$ att de har någon i sin nära omgivning med erfarenhet av akademiska studier (Eriksson m. fl. 2002: 11) och att de kan få stöd med studierna därifrån. Motsvarande siffra i min undersökning var 71,1\%, alltså något lägre.

Av studenterna i Växjöundersökningen har $10 \%$ utländsk bakgrund, vilket är något lägre än för riket i stort, där 17\% uppges ha utländsk bakgrund. I min undersökning svarade 12,8\% av studenterna att de har annat modersmål än svenska. Etnicitet som sådan är inte mitt fokus, och jag avstår därför från att utveckla frågan om etnicitet och högskolestudier vidare här.

Min undersökning visar dessutom att drygt hälften av studenterna har gått ett studieförberedande program $(58,7 \%)$ på gymnasieskolan, och knappt hälften $(46,1 \%)$ har gått ett yrkesförberedande program. Totalt 70,5 \% av studenterna i undersökningen uppger att de inte känner att den svenskundervisning de tagit del av på gymnasieskolan förberett dem för det akademiska skrivande de ställdes inför på universitetsnivå. Liknande resultat redovisas även i min licentiatavhandling (Ask 2005b: 102 ff). Många av studenterna har också erfarenhet av Komvuxstudier och yrkesarbete. Ett stort antal studenter har alltså ytterligare utbildningserfarenheter med sig in på universitetet. Nästan hälften $(44,7 \%)$ har utbildat sig vidare efter gymnasiet innan de valde att utbilda sig till lärare. En stor majoritet av studenterna $(73,3 \%)$ inriktar sig på en lärarutbildning för undervisning av de tidigare skolåren, resterande mot grundskolan och gymnasieskolan. 


\section{Lärarstudenten och skrivandet}

Jag skall nu efter att den större och mer övergripande enkätundersökningen nämnts, redovisa min egen enkätundersökning "Studenters skrivande" ${ }^{1}$ mot bakgrund av den större undersökningen av Växjöstudenterna. Min fokus för enkäten var studenternas uppfattning om det akademiska skrivandet, en vinkling som inte finns i den större undersökningen.

Under vårterminen 2006 skrev 165 lärarstudenter vid Växjö universitet sitt examensarbete. I enkätundersökningen kallad "Studenters skrivande" ville jag undersöka hur dessa studenter ser på sin språkliga utveckling i slutet av sin utbildning och vilken attityd de har till akademiskt skrivande. Resultatet av enkäten redovisas nedan. Enkätfrågorna återfinns i bilaga A.

Sammanlagt deltog 78 studenter i min enkät "Studenters skrivande". Enkäten genomfördes under vårterminen 2006 och skickades ut till studenterna elektroniskt via en länk till en webbsida där frågorna kunde besvaras. Svarsfrekvensen (47\%) får ses som relativt låg då totalt 165 studenter erbjöds att vara med. Enligt min erfarenhet är inte frågor om skrivande och skriftspråksutveckling något studenter finner lika intressant som forskare gör. Min förhoppning är att de studenter som bemödat sig om att svara gjorde det för att de kände att det var meningsfullt att de fick säga sin mening om det akademiska skrivandet. Men detta innebär också att det var ett positivt urval i den betydelsen att studenterna "valde sig själva".

\section{"Från acceptabelt till akademiskt"}

På frågan "Hur har ditt skriftspråk förändrats under tiden på universitetet?" svarar de allra flesta studenter i min enkät att de upplever en positiv utveckling av den egna skrivförmågan. Någon svarar kort: "Från acceptabelt till akademiskt" (ES s. 8), men för inga vidare resonemang om vad en sådan utveckling skulle kunna innehålla. Formuleringar som "det har blivit mer akademiskt" och motsvarande tolkar jag som att studenten upplever en positiv utveckling. Återkommande i enkätsvaren är att studenterna tycker att de har ökat sitt ordförråd, blivit mer korrekta och lärt sig skriva mer varierat, logiskt och strukturerat. Några studentröster:

(1) Jag känner mig mycket säkrare på att skriva texter, även om jag aldrig upplevt att jag har haft direkt svårt för att skriva jag anser själv att jag skriver på ett akademiskt och korrekt sätt. Jag kan också skriva på ett sätt så att det passar mottagaren. (ES s.7)

(2) Positivt. Studierna på universitet har både utökat mitt ordförråd samt förbättrat mig i att uttrycka mig skriftligt. (ES s.7)

(3) Det pratiga och allmänna tyckandet har stramats upp. Jag analyserar mer vad det frågas efter och försöker skriva logiskt och följa en struktur utefter frågeställningen. (ES s. 8)

Av deltagarna i undersökningen anser åtta studenter att de bara upplevt viss utveckling eller att de inte själva kan avgöra om de utvecklats eller inte. Någon menar att språket inte utvecklats alls. De fall där studenterna explicit ger uttryck för en negativ utveckling är få, och

1 Enkätsammanställningen "Studenters skrivande" i sin helhet finns i arkivet på Institutionen för humaniora vid Växjö universitet och kan rekvireras på begäran. I citatreferenserna anges hädanefter ES (enkätsammanställning) och aktuellt sidnummer. 
de hörs i utsagor som: "Jag har blivit bättre på att ordbajsa ... dvs skriva saker krångligare" (ES s. 7) och "Ja, men jag skulle säga att mitt [språk] innan skolstarten var mer alldagligt och nu mer högtravande otrevligt" (ES s. 9). En student menar att språket inte utvecklats i särskilt stor omfattning "eftersom allt bara har blivit stressigt" (ES s.9).

\section{Individuella skriftspråkhistorier}

En individs samlade upplevelser av sitt språk och vittnesbörd som har med det egna skrivandet att göra kan föras samman i vad som kallas individuella språkhistorier (Alvtörn 2005, Arvidsson 2005). Studenterna ombads i enkäten att fritt skriva sina individuella skriftspråkshistorier, från tiden för övergången till högre utbildning och fram till examensarbetet på lärarutbildningen. Detta visade sig vara en svår uppgift. Många svar var knapphändiga eller irrelevanta i sammanhanget. Nedan lyfter jag fram två studenters röster, då de på ett något utförligare vis reflekterar över sin utveckling under utbildningstiden. Den första studenten är uttalat positivt inställd till sin egen skriftspråksutveckling:

(4) Jag anser att mitt skriftspråk har förbättrats betydligt under mina studier på universitetet. På gymnasiet fick jag inte lära mig att till exempel referera till litteratur och att citera på ett korrekt sätt under min gymnasiala utbildning. Jag tycker att den "undervisning” som jag fick kring skrivande i min inriktning i svenska var till stor hjälp för mig. Läsning av litteratur om universitetsskrivandet har varit en faktor till förbättrandet av mitt skriftspråk. Nu när jag skriver mitt examensarbete anser jag att det inte är det språkliga som är komplicerat utan det som var svårast var att komma på ett problem som var intressant. (ES s. 8)

I citatet ovan ger studenten en bild av hur hon har utvecklat sitt akademiska skrivande under sin utbildningstid, trots att den skriftliga förberedelsen på gymnasieskolan inte upplevdes som tillräcklig. Studenten nedan är också positiv till den egna utvecklingen, men är osäker på nyttan av den nyförvärvade färdigheten i en framtida lärarroll:

(5) Trodde inte jag skulle utvecklas så mycket på detta sätt, men det är roligt att läsa texter från början av utbildningen och jämföra med nyare - för att se förändring. Jag kan tänka mig att jag nu i texter kan krångla in mig för mycket, så att det blir för byråkratiskt för utomstående att läsa. När jag fortfarande är kvar på universitetet är det därför jättebra att ha handledare som påpekar och ber mig ändra för att språket ska bli läsligt för alla. Det är lite tråkigt att tänka att man har utvecklats så mycket på detta område och att man senare i sitt yrke kanske inte kommer att ha så mycket nytta av det. En intensiv period i mitt liv som har gjort att jag känner mig proffsigare i min yrkesroll och jag ser skrivandet som en del av det. Jag har även läst litteratur och artiklar som numera är lättare att förstå och analysera. Jag känner mej också påläst och ser utvecklingen i språket och historien om det blir en aha upplevelse. (ES s. 27)

Gymnasieskolans svenskundervisning har, enligt den här studenten, inte genererat de verktyg studenten behöver ha i det akademiska skrivandet. Detta diskuteras utförligt i (Ask \& Sandblad 2003, Ask 2005a, 2005b). Utvecklingen beskriver studenten därför som lite förvånande, men dock positiv. Säkerligen har studentens ämnesstudier i svenska haft positiv påverkan i det här fallet. Studentens förhållande till skrivandet i en framtida yrkesroll är ambivalent. $\AA$ ena sidan anser studenten att det är synd att "man senare i sitt yrke kanske inte kommer att ha så mycket nytta av det", å andra tänker studenten att hon känner sig "proffsigare i sin yrkesroll och att skrivandet är en del av det". Ambivalensen kan tolkas 
som en osäkerhet inför vad läraryrket kommer att ställa för krav på individens skriftspråkliga kompetens. Inför skrivandet av examensarbetet säger den här studenten att det inte längre är det akademiska språket i sig som är problematiskt utan att formulera en intressant fråga som är värd att utreda. Den insikten är central för att en individ ska kunna inbegripa sig i den vetenskapliga diskursen och får en djupare förståelse av det vetenskapliga samtalet.

Två studentröster talar om det akademiska skriftspråket som något opersonligt, auktoritärt och världsfrånvänt i beskrivningen av sin individuella skriftspråkshistoria:

(6) Man insåg ganska snabbt att den formen av skrift som vi använde oss av i gymnasiet, inte var välkommen här. Det förväntades att man skulle ta in "den nya ordningen" av skriftspråk utan ifrågasättande. Visst har jag lärt mig nya vackra ord men det kommer knappast att hjälpa mig i undervisningen mest eftersom eleverna inte kommer att förstå vad jag säger. (ES s. 26)

(7) Jag har till min irritation fått se mitt språk "förfalla” från poetiskt "mellanraderna” känslomässigt stort och innehållsrikt till ett mera politiskt korrekt språkbruk baserat på mer eller mindre "stulna" citat och ordvändningar. Jag hade velat, och vill i och för sig fortfarande, att inte bara vetenskapen styr det akademiska språket, utan även att människan ska kunna synas bakom språket. (ES s. 27)

Att uppleva att man inte får ifrågasätta den nya diskursen samtidigt som de färdigheter och erfarenheter av skrivande som studenterna har med sig från gymnasieskolan inte längre är tillräckliga, leder till frustration hos många studenter. Studenten bakom citat 6 ovan ser inte det akademiska språket som relevant för sin framtida yrkesroll, vilket gör den akademiska skriftspråkskompetensen till en isolerad färdighet som bara är viktig under studietiden. En liknande åsikt om utbildningen som en isolerad angelägenhet uttrycks av en tredje student:

(8) Hela universitetet lever i sin alldeles egna lilla bubbla och den trivs där men den har inte en susning om vad som händer utanför. (ES s.30)

Indignationen över att få sitt språk "förstört" hörs i det andra citatet där problemet för studenten är att vetenskap och människa inte tycks kunna mötas i de språkliga uttrycken. Uppfattningen om att människan bakom språket inte får synas är en spegling av studentens uppfattningar om regler, normer och konventioner rörande det akademiska språket. Visst finns det ett korn av sanning $i$ att opersonlighet ofta framhålls som decorum för akademiska texter, eftersom målet för god forskning är att ställa sakförhållandet, inte den egna individen, i centrum för argumentationen. Det behöver inte betyda att människan bakom språket inte får synas, men det krävs erfarenhet och språklig fingertoppskänsla för att balansera den personliga närvaron i akademiska texter.

\section{Vägar till ett akademiskt skriftspråk}

Nedan redovisas svaren på frågan "Hur har du gjort för att för att lära dig skriva akademiskt?" De svar som framkommer här ger en indikation om vad studenterna i undersökningen själva anser vara möjliga vägar till ett akademiskt skriftspråk. Främst handlar det om kontinuerlig träning, litteraturläsning och respons från lärare och studiekamrater, men också lyssnande, diskussioner och rådgivning $i$ Textverkstaden ${ }^{2}$ lyfts fram som möjliga vägar till ett akade-

2 För information om Växjö universitets Textverkstad, se www.hum.vxu.se/textverkstad/ 
miskt skriftspråk. "Imitera text och språk" (ES s. 13) är ett studentsvar som i olika utformning återkommer i många av de svar som redovisas nedan. Det handlar om att på olika sätt hitta mönster för de egna texterna och att imitera de specifika drag som gör att texter blir accepterade i den akademiska miljön.

\section{Övning ger färdighet}

Mest framträdande är den vikt som studenterna i undersökningen lägger vid att skriva mycket och ofta. Att ständigt tvingas att skriva texter av olika slag är en starkt bidragande faktor i sammanhanget. Här följer några studentröster:

(9) Har inte gjort något speciellt. Det har bara blivit att man har skrivit mer akademiskt ju fler texter man har skrivit. (ES s.10)

(10) Genom att öva och dels genom att ha fått råd av mamma. (ES s. 10)

(11) Skrivit, läst, skrivit, läst... (ES s. 10)

(12) Fått öva mycket genom inlämningsuppgifter, PM, uppsatser, hemtentor, arbeten etc etc. (ES s.10)

Det är tydligt att studenterna anser att ständigt skrivande är viktigt för skrivutvecklingen. Studenterna tvingas till mycket akademiskt skrivande på universitetet, och de får på så sätt träning som sker automatiskt och kontinuerligt. "Övning ger färdighet" är en sentens som återkommer ett flertal gånger i enkätsvaren. Också lärare och handledare tillskrivs betydelse, men inte alltid i positiv bemärkelse. En student kommenterar:

(13) Lärarna - man skriver inte för sig själv utan vad man tror att de vill att man ska skriva, vilket inte är så inspirerande” (ES s. 13).

\section{Textmönster i andras texter}

Studenterna uppger att både kurslitteratur i olika ämnen och litteratur som behandlar skrivandet har varit värdefulla i processen att tillägna sig ett akademiskt skriftspråk. Studenterna läser akademisk litteratur av olika slag i syfte att hämta textmönster som gör att de själva blir bättre skribenter. Så här säger några studenter:

(14) Läst litteratur av akademiskt grund. (ES s. 11)

(15) Jag har studerat den kurslitteratur vi haft och andra akademiska texter och försökt ta till mig det som verkar bra och dess regler. (ES s. 11)

(16) Jag har övat mig och skriva och tagit del av andra akademiska texter för att bekanta mig med språket. Sedan har jag fått hjälp av vänner och textverkstan. (ES s. 12)

Av citaten framgår att en del studenter läser akademiska texter utanför kurslitteraturen med det direkta syftet att hitta mönster för det egna skrivandet.

Att läsa andra studenters texter är också en återkommande strategi hos studenterna. Det handlar om att läsa andras texter för att hitta inspiration och mönster för det egna skrivandet:

(17) Läst vad andra har skrivit, kompisar och lärare som gett inspiration och hjälp att utveckla mig. (ES s. 11) 
(18) Tränat att skriva pm och tittat på hur andra har skrivit olika paper och dylikt. (ES s. 10)

(19) Jag har tittat på hur andra rapporter/uppsatser varit utformade och också genom all litteratur man läst under dessa år har gjort att man lärt sig skriva akademiskt. (ES s. 11)

(20) Läst andras examensarbeten. Jag har också använt mig av SAOL för att vara noggrann med stavningen. (ES s. 11)

Kurslitteratur i sig anses alltså vara en möjlig plats att hämta mönster från för det egna skrivandet: "All litteratur som man har läst under tiden på utbildningen har bidragit till stor del" (ES s. 11), säger exempelvis en student i undersökningen.

Många studenter läser även handböcker om skrivande och använder ordböcker och regelsamlingar etc. för att utveckla sitt skrivande. Exempel på verk som omnämns i enkätsvaren är Skrivboken (Strömquist 2005), SAOL (Svenska akademien 2006) och Svenska skrivregler (Svenska språknämnden 2005). Några studentröster om kurslitteraturläsning om skrivande:

(21) Läst studentlitteratur och skrivit mycket, bekantat mig med synonymordlistan. (ES s. 11)

(22) Läst kursböcker och använt metod- och skrivböcker, så att man känner till regler osv. (ES s. 11)

(23) Jag har läst litteratur som behandlar till exempel rapport- och uppsatsskrivning. Min mamma och pappa har också varit till stor hjälp. Studenter som jag har studerat tillsammans med och som läst fler kurser innan och som på så sätt har ett utvecklat akademiskt skrivande har också kunnat hjälpa mig. Den föreläsare som jag hade i svenskan har också lärt ut det akademiska skrivandet. (ES s. 12)

(24) [...] Skrivboken är också en klippa. (ES s. 11)

För att hitta mönster för det egna skrivandet läser alltså studenter kurslitteratur, annan akademisk litteratur och skrivhandböcker. Men de använder också andra studenters texter på olika nivåer för att imitera textmönster och hitta normer för det akademiska skrivandet.

\section{Respons på text}

Läsa och skriva mycket akademisk text ses alltså som de två viktigaste vägarna till ett akademiskt skriftspråk. Men också olika typer av respons på texter är viktigt för studenternas utveckling. Denna respons kan dels ges skriftligt, dels muntligt i diskussioner med lärare och handledare. Så här berättar några studenter hur responsgivande kan gå till:

(25) Lyssnat på handledare, kollat böcker och låtit skrivandet få ta tid. (ES s. 11)

(26) Tagit del av lärarnas krav av hur man ska skriva. (ES s. 13)

(27) Diskuterat med handledare och studiekamrater. (ES s. 11)

(28) Tagit mot tips och idéer från andra studenter och släktingar. Samt läst lite hur man kan skriva bättre. (ES s.12)

Inte bara lärare och handledare är viktiga i responsprocessen. I rösterna ovan skymtar också vänner, släktingar, föräldrar och syskon fram som möjliga textkritiker och responsgivare. Det är rimligt att anta att responsen varierar i innehåll och utformning. En ytterpol på skalan offentlig - privat är den institutionaliserade lärarresponsen, en annan är den mer 
privata responsen som vänner och familj utanför universitetet kan stå till tjänst med. Mellan lärarauktoriteten och mammas korrekturläsning befinner sig responsgivandet som andra studenter står för. Studenter i undersökningen skriver att de drar nytta av alla tre varianterna.

Nätverket runt en student kan givetvis se olika ut, men påfallande ofta visar materialet att närstående spelar en stor roll för studenters skrivande på universitetet. Föräldrars och andra närståendes intresse för och inställning till studentens högskolestudier undersöks också av Eriksson m.fl. (2002). Där framkommer att de flesta studenter upplever att närstående är intresserade av - men inte alltid så kunniga om - vad det är studenterna egentligen gör (Eriksson m. fl. 2002:13). Motsatta erfarenheter uttrycker klassresenärerna hos Trondman (1994: 183 ff) där utbildning och högskolestudier främst ses som individens ensak och inte något som familjen behövde ta del av eller intressera sig för.

\section{Övriga vägar}

Tre studenter lyfter fram deltagande i muntliga aktiviteter som en källa till kunskap om det akademiska skrivandet. Någon menar att lyssnandet är centralt: "Lärde mig genom att läsa texter och lyssna på föreläsningar", medan andra muntligen har diskuterat text och skrivande "med lärare och andra studenter". Även rådgivningsverksamheten på Textverkstaden är central för en mindre grupp studenter. I övrigt nämner studenter med ämnesinriktning svenska att ämnesstudierna spelat stor roll för utvecklingen av deras akademiska skriftspråk, vilket inte är så överraskande. Språkstudier i allmänhet framhålls också som ett bra sätt att lära sig skriva akademiskt.

\section{Värdering av vägarna}

Studenterna i undersökningen blev ombedda att värdera hur viktiga de upplever de olika vägar till ett akademiskt skriftspråk som presenterats ovan. Resultatet presentera i figur 1 nedan. För överskådlighetens skull har svarskategorierna Mycket viktigt och Viktigt samt kategorierna Oviktigt och Mycket oviktigt lagts samman.

Faktorer som påverkar skrivandet

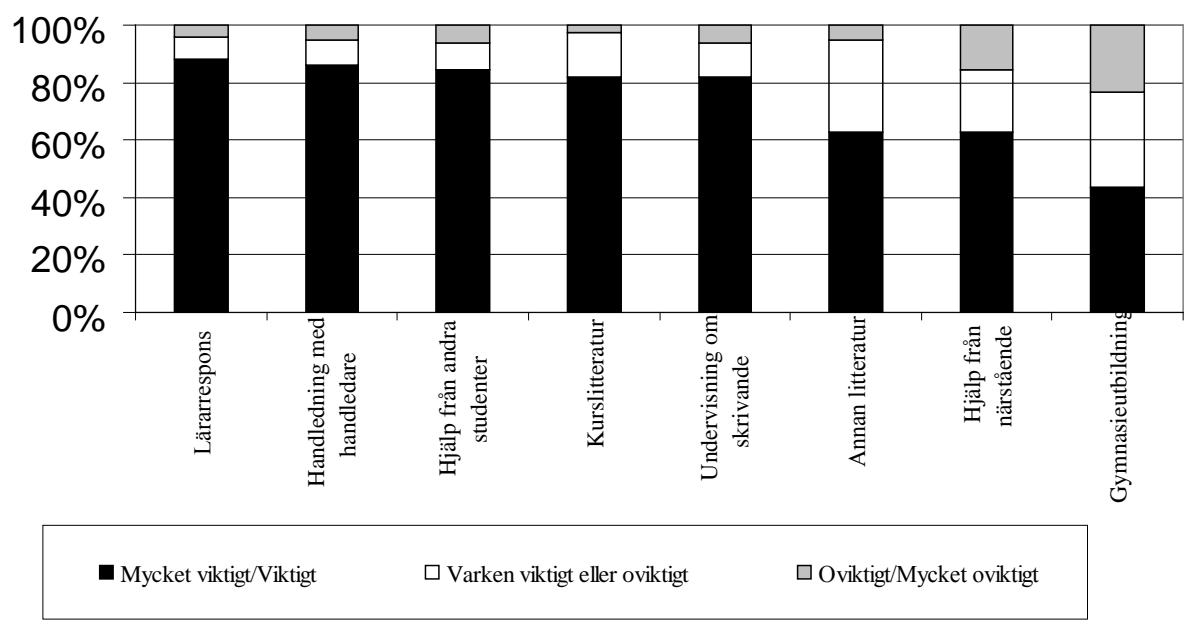

Figur 1. Faktorer som påverkar skrivandet. Staplarna visar i fallande ordning hur studenterna värderar olika sätt att tillägna sig kunskap om och färdighet i det akademiska skrivandet. 
Resultaten visar att studenterna värderar lärarrespons som allra viktigast för utvecklingen av det akademiska skrivandet, tätt följt av handledning med handledare och hjälp från andra studenter. Det är alltså enligt studenternas mening främst interpersonella kontakter öga mot öga som ger de bästa möjligheterna att utveckla ett akademiskt skriftspråk. Att läsa kurslitteratur och annan akademisk litteratur är en mer opersonligt inriktad aktivitet som går långsamt och kräver en aktiv insats av studenten själv. Kurslitteratur anses vara viktigare än annan litteratur, vilket säkerligen har att göra med att det är svårt att orka och hinna med att läsa mer än det som står på litteraturlistorna. De mer opersonliga vägarna rankas inte lika högt som de interpersonella.

Undervisning om skrivandet intar här en intressant särställning. Det är ett slags mellanting mellan interpersonell och opersonlig aktivitet, beroende på undervisningens utformning. Eftersom studenterna representerar många olika ämnesmiljöer på universitetet är det rimligt att anta att det också påverkat hur de har värderat undervisning om skrivandet. Påfallande är att undervisning om skrivandet rankas som mindre viktigt än hjälp från andra studenter. Det är därför centralt att föra didaktiska resonemang om förhållandet mellan undervisning om skrivandet och studenternas uppfattningar om detsamma. Gymnasieutbildning, slutligen, skattas som minst viktigt, vilket kan tillskrivas det faktum att studenter ofta upplever att tidigare utbildning spelar en liten roll i den nya diskursen.

\section{Hinder på vägen}

Ur svaren på frågan "Vad skulle du ha velat ha annorlunda när det gäller din utveckling av ett akademiskt skriftspråk?" utkristalliserar sig olika hinder för språkutveckling som studenterna har upplevt under sin studietid. Detta verkar vara en svår fråga att svara på och många har svarat "vet inte" eller lämnat frågan utan att besvara den. Några studenter anger också att de inte skulle vilja ha haft det annorlunda och att de är nöjda med hur deras skrivande utvecklats. Exempel på sådana positiva röster är "Jag tycker att jag genomgår en sund utveckling med upp- och nedgångar" (ES s. 18) och "Inget. Jag känner mig nöjd" (ES s. 18). Att språket är en ingångsport till framgång på universitet är studenterna på det klara med. En student tänker på vad som kunde ha varit annorlunda och hamnar i tankar om sig själv och effekten av att inte ha ett skriftspråk som kan bära fram de tankar som finns: "Jag önskar jag kunde röra mig mer med 'fina ord' och få ett bättre skrift språk. På ex. tentor vet jag för det mesta vad som är svaret men har svårt att formulera texten" (ES s. 16).

Mest framträdande i svaren på frågan om vad som kunde ha varit annorlunda är studenternas önskemål om fler föreläsningar och mer explicit undervisning om skrivandet. De hävdar också att sådan undervisning borde vara obligatorisk i alla universitetsutbildningar. Studenterna vill också ha mer tid anslagen till akademiskt skrivande i alla utbildningar. En student skriver:

(29) Fler korta skrivuppgifter som hade bedömts med hänsyn tagen både till innehåll och form. Klart redovisade motiv till varför man måste skriva på ett visst sätt. (ES s. 18)

Det är alltså inte bara form och formalia de här studenterna vill ha hjälp med, utan de vill också ha hjälp med det vetenskapliga tänkandet i den nya miljön. En student uttrycker det så 
här: "någon som går igenom fel som uppstår, men även att någon går igenom hur man ska tänka och vad som ska finnas med i en text" (ES s. 17). De vill också få hjälp med att inlemmas i miljön och saknar klara motiveringar till varför de ska skriva som de gör.

Att det inte finns konsekventa krav på skrivandet hos lärare och institutioner inom universitetet är också något som studenterna lyfter fram som en brist. De upplever att det är "lite jobbigt att alla institutioner har olika 'mallar' på hur man bör skriva" (ES s. 17) och ett önskemål om "konsekvens inom universitetets olika institutioner så man slapp lära sig hur man ska skriva på vilken för att bli godkänd" (ES s. 16). Någon student påpekar också att språk och språkbehandling inte alltid får samma uppmärksamhet inom olika ämnen och discipliner och anser att det hade varit bättre om alla lärare och examinatorer tycker att en god språkhantering är något mycket viktigt. Lärarens roll i sammanhanget är alltså central och studenterna hade önskat "att kunna arbeta i delar med handledarstöd" (ES s. 17) och med "mer hjälpsamma lärare" (ES s. 18). Kontinuerlig respons från lärare är något flera studenter efterlyser. En student skriver följande om detta:

(30) Feedback från lärarna och då inte när kursen är slut utan under tiden så man kan utvecklas om man har några frågor. Det som man inte vet när man gör fel. Eftersom man inte får feedback vet man inte vad man gör bra och inte så bra. Detta är ett önskemål. Ge feedback. Detta saknade jag även i grundskolan och i gymnasiet en del. (ES s. 17)

Behovet av en mer interpersonell stödstruktur runt studenterna kan tolkas på fler sätt. Det skulle kunna tyda på en kollektiv ökad osäkerhet hos nya studentgrupper som saknar akademisk socialisation i närmiljön, men det skulle också kunna var ett utslag av individuell osjälvständighet och frustration i ett ogenomskinligt system. Symptomen på både den kollektiva osäkerheten och individens osjälvständighet blir de allt vanligare ropen efter "mallar", mer feedback, skriftspråklig konsekvens mellan institutioner och ämnen, handledarstöd och ökade undervisningsinsatser om skrivandet i högre utbildning.

\section{Didaktiska utmaningar}

I den redovisade undersökningen beskrivs inträdet i den akademiska diskursen ur ett studentperspektiv. Att behärska det akademiska skrivandets egenheter blir en inträdesbiljett till den vetenskapliga gemenskapen men också till framgång i studierna. Studenterna i enkäten ger sammantaget en komplex bild av vilka olika vägar de väljer då de försöker tillägna sig ett akademiskt skriftspråk. De främsta vägarna till ett akademiskt skriftspråk innebär interpersonella relationer i samband med skrivandet, men det är inte självklart att de får de personliga möten de eftersträvar i en akademisk miljö präglad av självständighet och individuella sätt att arbeta. Studenterna upplever också hinder på sin väg. Det handlar om fenomen i universitetsmiljön och i undervisningssituationen: inkonsekvens, frustration, lärare som inte upplevs som hjälpsamma och utebliven respons på text är några exempel. Men det handlar också om kognitiv osäkerhet hos individen; studenterna frågar sig hur man egentligen ska tänka på universitetet och hur man kan bearbeta den frustration som kommer av att veta vad man vill säga samtidigt som man vet att man inte kan säga det på rätt sätt.

Ur ett didaktiskt perspektiv finns all anledning att lyfta upp de problem i universitetsmiljön som studenterna menar är hinder för utveckling. Det är på ett vis smärtsamt att erfara att 
studenter värderar hjälp från andra studenter högre än den undervisning om skrivande som vi universitetslärare bedriver. Samtidigt är det tydligt att de allt mer heterogena studentgrupperna utgör pedagogiska utmaningar för undervisande lärare. Dilemmat är att lärare både vill värna akademins tradition och särart samtidigt som de tvingas anpassa sig till en föränderlig omvärld med individer som lär, utvecklas och förhåller sig till det akademiska skrivandet på ett annat sätt än de är vana vid och förväntar sig. Genom att belysa de problemfält - och de möjligheter - som ett studentperspektiv på skrivforskning genererar finns en didaktisk utvecklingspotential som både lärare och studenter skulle kunna gynnas av.

\section{Litteratur}

Alvtörn, Lovisa, 2005: En människas språkhistoria i ljuset av ett vidgat lektbegrepp. D-uppsats, Lunds universitet.

Arvidsson, Alf, 2005: Livet som berättelse studier i levnadshistoriska intervjuer. Etnologiska skrifter, 10. Studentlitteratur, Lund.

Ask, Sofia, 2005a: Röster i övergången. Nya studenter om skrivandet i högre utbildning. I: Med textverkstaden i centrum. Erfarenheter och forskning om studenters akademiska skrivande. Red: Lindgren, M. Rapporter från Växjö universitet. Humaniora. Nr 14/2005. Växjö.

Ask, Sofia, 2005b: Tillgång till framgång: lärare och studenter om stadieövergången till högre utbildning. Licentiatavhandling. Växjö universitet Institutionen för humaniora, Växjö.

Ask, Sofia \& Sandblad, Fredrik, 2003: Stadieövergångar och textvärldar. Om nyblivna studenter som möter högskolans textvärld. www.hum.vxu.se/publ/ humanetten/nummer12/art0302.html [Hämtat 2005-01-15].

Brandell, Sara \& Höög, Helena, 1998: Med studenternas egna ord: svaren på två öppna frågor i en enkät hösten 1996 till studenter $i$ Sverige. Arbetsrapport / Studenterna i Sverige - Studs, 3. Högskoleverket, Stockholm.

Eriksson, Magnus, Lundberg, Eva \& Olofsson, Gunnar, 2002: Växjöstudenterna och deras universitet: en studie av studenternas bakgrund, förhållningssätt och studievanor. Rapport från Institutionen för samhällsvetenskap, 16. Växjö universitet, Växjö.

Melander Marttala, Ulla, 2006: Hur går studierna? Om studieframgång i två studentgrupper. I: Svenskans beskrivning 2005. Red: Ledin, P. Örebro Universitet.

SCB, 2005: Pressmeddelande från SCB 2006-04-27 09:30 Nr 2006:096. www.scb.se/ templates/pressinfo_165914.asp [Hämtat 2006-06-18].

Skolverket, 2005: Väl förberedd? Arbetsledare och lärare på högskolor bedömer gymnasieutbildades färdigheter. En utvärdering av gymnasieskolan utifrån mottagarnas perspektiv. Rapport 268. Fritzes, Stockholm.

Staaf, Mikaela, 2002: Den nya lärarutbildningen. De nya studenternas åsikter om utbildningen höstterminen 2002. Enheten för kvalitet och utvärdering vid Uppsala universitet, Uppsala.

Staaf, Mikaela, 2004: Den nya lärarutbildningen. En undersökning av studenterna på fjärde terminen och deras åsikter om utbildningen. Enheten för kvalitet och utvärdering vid Uppsala universitet, Uppsala. 
Staaf, Mikaela, 2006: Den nya lärarutbildningen. En undersökning av kull ht-02 om studenterna och deras åsikt om utbildningen på sjunde terminen. Enheten för kvalitet och utvärdering vid Uppsala universitet, Uppsala.

Strömquist, Siv, 2005: Skrivboken: skrivprocess, skrivråd och skrivstrategier. Gleerup, Malmö.

Svenska akademien, 2006: Svenska akademiens ordlista över svenska språket. Svenska akademien: Norstedts akademiska förlag distributör, Stockholm.

Svenska språknämnden, 2005: Svenska skrivregler. Skrifter utgivna av Svenska språknämnden, 82. Liber, Stockholm.

Trondman, Mats, 1994: Bilden av en klassresa: sexton arbetarklassbarn på väg till och $i$ högskolan. Carlsson, Stockholm.

ÖGUS, 2006: Övergången från gymnasieskola till universitet. Otryckt material.

BILAGA A

Enkät 2005

Sofia Ask

\section{(6) Växjö universitet}

1. Född år

$\operatorname{man} \quad \square \quad$ kvinna

2. Talar andra språk än svenska

I så fall vilket/vilka?

3. Civilstånd

Barn

4. Gymnasieutbildning (program eller motsvarande)

Ev. annan utbildning

5. Inträde på lärarutbildningen år

Examen planerad $\quad$ år

Inriktning på lärarutbildningen

Ämne/n

Jag planerar att skriva mitt examensarbete om

6a. Finns det personer i din närhet med erfarenhet av akademiska studier som du kan få allmänt stöd av?

6b. Kan du få hjälp av dem med själva skrivandet?

7. Föräldrarnas yrken och utbildning

mor:

far: 


\section{Om ditt skrivande}

8. Hur har ditt skriftspråk förändrats under utbildningen?

9. Vilka hinder för din skrivutveckling har du upplevt under din universitetstid?

10. Den akademiska skrivförmåga du visar i dina texter - hur har du erövrat den?

11. Vad har mest påverkat ditt skrivande, tror $\mathrm{du}$ ?

12. Tänk tillbaka! Vad hade du önskat hade varit annorlunda om du tänker tillbaka på din skriftspråksutveckling på universitetet?

13. Värdera i vilken grad följande faktorer påverkat ditt skrivande på universitetet. (1 är oviktigt, 5 är mycket viktigt).

Undervisning om skrivande

$$
1
$$$$
2
$$$$
3
$$$$
4
$$$$
5
$$

Handledning med handledare

$$
1
$$$$
2
$$$$
3
$$

Lärarrespons

1

2

$\begin{array}{lll}3 & 4 & 5\end{array}$

Kurslitteratur

Litteratur du hittat själv

$$
1
$$

2

$\begin{array}{lll}3 & 4 & 5\end{array}$

Rådgivning i Textverkstaden

$$
1
$$

2

Hjälp från närstående

1

2

$\begin{array}{lll}3 & 4 & 5\end{array}$

Hjälp från andra studenter

1

12

$\begin{array}{lll}3 & 4 & 5 \\ 3 & 4 & 5\end{array}$

Gymnasieutbildning

1

2

Annat (ange vad)

14. Skriv din individuella skriftspråkshistoria från övergången till universitetet och fram till examensarbetet. 